\title{
Infants and Young Children with Cystic Fibrosis Have High Levels of Serum Sialyl Lewis ${ }^{\text {a }}$ Antigen
}

\author{
RALPH C. FRATES, JR., SUSAN SCOTT, KEITH B. HAMMOND, JOHN O. BROOKS III, \\ C. JOAN RICHARDSON, AND DAVID D. ROBERTS \\ Department of Pediatrics, University of Texas Medical Schoolat Houston, Houston, Texas 77030 [R.C.F., \\ S.S.], Pediatric CRC Core Laboratory, The Children's Hospital, Denver, Colorado 80262 [K.B.A.], \\ Department of Psychiatry and Behavioral Sciences, Stanford University School of Medicine, Stanford, \\ California 94305 [J.O.B.], Department of Pediatrics, University of Texas Medical Branch, Galveston, \\ Texas 77550 [C.J.R.], and Laboratory of Pathology, National Cancer Institute, National Institutes of \\ Health, Bethesda, Maryland 20892 [D.D.R.]
}

\begin{abstract}
Previous studies suggest that scrum levels of the mucinassociated sialyl Lewis ${ }^{\text {a }}\left(\mathrm{Le}^{\mathrm{a}}\right.$ ) antigen (NeuAC $\alpha 2-3$ Gal $\beta 1-3$ [Fuc $\alpha 1-4]$ GlcNAc $\beta 1$. .) correlate with the pulmonary status of cystic fibrosis (CF) patients who have $\mathrm{Le}^{\mathrm{a}}$ or Lewis ${ }^{\mathrm{b}}$ blood types and can form the antigen. However, there is little information on serum sialyl Le antigen levels in CF patients or normal children younger than $9 \mathrm{y}$. We measurcd serum antigen levels using the MAb 19-9 in normal term neonates, CF infants and young children, and infants and children who had bronchopulmonary dysplasia or asthma. The mean serum sialyl Le antigen level of the CF patients was $46.7 \mathrm{U} / \mathrm{mL}$, significantly above $(p<0.01)$ the mean levels of the three other groups. The mean serum sialyl $\mathrm{Le}^{\mathrm{a}}$ levels of the three non-CF groups were not significantly
\end{abstract}

ABSTRACT
Since 1986, we and others have detected high levels of the sialyl Le ${ }^{\mathrm{a}}$ antigen (NeuAc $\alpha 2-3$ Gal $\beta 1-3$ [Fuc $\left.\alpha 1-4\right]$ GlcNAc $\beta 1-$ ...) in the sera of many CF patients (1-4). The antigen is present on mucins in the sera of patients with CF (5) and adults who have pancreatic or other gastrointestinal cancers. Sialyl $\mathrm{Le}^{\mathrm{a}}$ antigen may be used as a tumor marker (6). Sialyl Le antigen (or mucin) levels in serum are related to the age, clinical status, and pulmonary status of CF patients $(7,8)$. The purpose of the present study was to compare serum antigen levels of healthy newborns or infants and young children who had lung diseases (e.g. asthma or bronchopulmonary dysplasia) with serum antigen levels of infants and young children who had CF.

MAb that specifically recognize this carbohydrate epitope, including CA 19-9, have been used to quantify the antigen in patient sera (9). The antigen was originally examined as a tumor marker (6), but has limited utility for diagnostic pur-

Received March 24, 1993; accepted December 10, 1994.

Correspondence: Ralph C. Frates, Jr., M.D., Department of Pediatrics, University of Texas Medical School at Houston, MSB 3.228, 6431 Fannin Street, Houston, TX 77030.

Supported in part by Grant M01-RR00069, General Clinical Research Center Program, National Center for Research Resources, National Institutes of Health (K.B.H.). different from one another or from published normal values. We conclude that serum sialyl Le antigen levels are elevated early in $\mathrm{CF}$, but are normal in asthma and bronchopulmonary dysplasia patients. (Pediatr Res 37: 460-464, 1995)

$\quad$ Abbreviations
CA 19-9 carbohydrate antigen 19-9
CF, cystic fibrosis
CFTR, cystic fibrosis transmembrane conductance regulator
Le $e^{\mathrm{a}}$, Lewis ${ }^{\text {a }}$ blood group antigen
$\mathbf{L e}^{\mathrm{b}}$, Lewis ${ }^{\mathrm{b}}$ blood group antigen
$\mathbf{L e}^{\mathrm{a}-\mathbf{b}-}$, no detectable Lewis ${ }^{\text {a }}$ or Lewis $^{\mathrm{b}}$ antigen

poses, because expression of the antigen depends on expression of several gene products (10). Approximately $7 \%$ of the population lacks the Le gene, and the assay will be uninformative for these patients. Levels of antigen also vary due to competition by other glycosyltransferases for the precursor oligosaccharide Gal $\beta 1-3 \mathrm{GlcNAc} \beta 1-\mathrm{R}$ during biosynthesis of sialyl Le ${ }^{\mathrm{a}}(10-12)$. Thus, $\mathrm{Le}^{\mathrm{b}}$ patients, expressing both the Le and Se genes, have lower levels of antigen than $\mathrm{Le}^{\mathrm{a}}$ patients expressing only the Le gene (10-12). Therefore, absolute levels of antigen cannot be directly correlated with disease status in individual patients. By population studies and longitudinal studies of individual patients, however, antigen levels have been correlated with recurrence or progression of tumors in patients with mucin-secreting adenocarcinomas and with age, clinical status, and pulmonary status of patients with $\mathrm{CF}$ $(7,8)$.

\section{METHODS}

Chemical/immunologic. The Lewis blood group type of 111 healthy newborns was determined by a method similar to that of Karlsson and Larson (13). Newborns' meconium in labeled 
disposable diapers was promptly placed on dry ice in a Styrofoam container, which was then transported daily to the laboratory for storage in a $-70^{\circ} \mathrm{C}$ freezer in individual plastic bags. After thawing, glycolipid was extracted from $1 \mathrm{~g}$ wet weight of meconium by two extractions of chloroform:methanol:water (5:10:3) and desalted on Sephadex G-25 columns eluted with chloroform:methanol:water (60:30:4.5). Glycolipids were detected by immunostaining after separation on Merck HPTLC plates (14). Each sample was typed for its Lewis antigen using $\mathrm{MAb}$ to Lewis blood group antigens $\mathrm{Le}^{\mathrm{a}}$ and $\mathrm{Le}^{\mathrm{b}}$, produced by hybridoma cell lines 151-6-A7-9 and 143-Z-A6-11, respectively (American Type Culture Collection HB8324 and HB8325, Rockville, MD). For each sample, 1- and 5-mg equivalents of tissue were applied. Internal standards were total lipid extract from colorectal carcinoma cell line SW1116 (American Type Culture Collection HB8059) and human Le and $\mathrm{Le}^{\mathrm{b}}$ ceramide. ${ }^{125}$ I-labeled protein $\mathrm{A}$ and goat anti-mouse IgM were used to detect $\mathrm{Le}^{\mathrm{a}}$ and $\mathrm{L} \mathrm{e}^{\mathrm{b}}$ antibody binding, respectively. Plates were dried and exposed to Kodak XAR5 film.

Levels of sialyl Le $\mathrm{Le}^{\mathrm{a}}$ antigen in sera from umbilical cord blood of the newborns or from venous blood of babies or children were measured using CA 19-9 immunometric assay (kits were provided by Centocor, Malvern, PA). This method has been described by Del Villano and colleagues (9).

Patients. Four groups were studied, and the demographics of each are provided in Table 1 . All but three of the CF patients were initially detected by the neonatal immunoreactive trypsin assay (15). Their diagnoses were later confirmed by quantitative pilocarpine iontophoresis (16) with sweat chloride concentrations repeatedly greater than $60 \mathrm{mmol} / \mathrm{L}$. The CF patients' blood samples were obtained by phlebotomy while they were outpatients at the University of Colorado Health Sciences Center in Denver. Table 2 provides the CF patients' clinical characteristics. Genotypes for 26 of $39 \mathrm{CF}$ patients were determined by standard means (17).

The 38 asthmatic patients' venous blood was sampled while they were inpatients at the National Jewish Asthma Research Center in Denver. The Asthma Research Center inpatients usually have asthma that is severe and refractory to treatment.

The 17 bronchopulmonary dysplasia patients had all suffered stage IV lung disease (18) and some were oxygen-dependent at the time their venous blood was sampled during clinic visits at the University of Colorado Health Sciences.

The 111 neonates were all term infants who generally had Apgar scores greater than 7 at 1 and 5 min after delivery. Two sick neonates were inadvertently included. One term neonate had Apgar scores of 4 at 1 min and 9 at 5 min and was later

Table 1. Characteristics of patients tested for serum sialyl Le ${ }^{a}$ (mucin)

\begin{tabular}{lcccc}
\hline \multicolumn{1}{c}{ Diagnosis } & $\begin{array}{c}\text { Number of } \\
\text { patients }\end{array}$ & $\begin{array}{c}\text { Male/ } \\
\text { Femalc }\end{array}$ & $\begin{array}{c}\text { Average } \\
\text { age }\end{array}$ & Age range \\
\hline $\mathrm{CF}$ & 39 & $19 / 20$ & $13.7(11.1) \mathrm{mo}$ & $1-37 \mathrm{mo}$ \\
Asthma & 38 & $12 / 26$ & $10(3.3) \mathrm{y}$ & $2-16 \mathrm{y}$ \\
$\begin{array}{c}\text { Bronchopulmonary } \\
\quad \text { dysplasia }\end{array}$ & 17 & $5 / 12$ & $10.2(5.8) \mathrm{mo}$ & $3-23 \mathrm{mo}$ \\
$\begin{array}{l}\text { Normal term neonates } \\
\text { Norman }\end{array}$ & 111 & $61 / 50$ & $1 \mathrm{~d}$ & $1 \mathrm{~d}$ \\
\hline
\end{tabular}

$\mathrm{SD}$ are in parentheses.
Table 2. Clinical characteristics of $C F$ patients

No complaints, findings, or chest roentgenogram changes

Only gastrointestinal or nutritional complaints or findings

Respiratory complaints (no changes in physical examination or chest roentgenogram)

Respiratory complaint with positive physical finding (but no chest roentgenogram changes)

Respiratory complaint, either or both physical findings and/or chest rocntgenogram changes

No complaint or physical finding, but chest roentgenogram changed

Total

determined to have CF. Blood was obtained postpartum from an umbilical vein of the placenta. The specimens from neonates were obtained at the University of Texas Medical Branch, Galveston, TX, and Fairfax Hospital, Fairfax, VA. The study protocol was approved by the institutional review boards of the institutions involved.

Statistical analyses. A one-way analysis of variance $(1 \times 4)$ with groups as a between-subjects factor was conducted to determine whether the mean serum antigen levels of the four groups differed. Duncan's multiple range test was used to evaluate the differences among the group's mean serum antigen levels. Pearson correlation coefficients were used to determine the relation between serum antigen level and patients' age and gender. A $t$ test for two groups of unequal size (two-tailed) was used to determine the significance of differences between mean serum antigen levels of $\mathrm{Le}^{\mathrm{a}}$ or $\mathrm{Le}^{\mathrm{b}}$ neonates and mean serum antigen levels of CF patients with respiratory complaints compared with those CF patients with either no disease or who had gastrointestinal or nutritional manifestations of CF. Data are expressed as mean units of antigen per $\mathrm{mL}$ of serum \pm SEM.

\section{RESULTS}

Our major finding was that the CF patients' mean serum sialyl Le ${ }^{a}$ antigen level was significantly higher than the mean serum antigen levels of the other three groups (Fig. 1). The

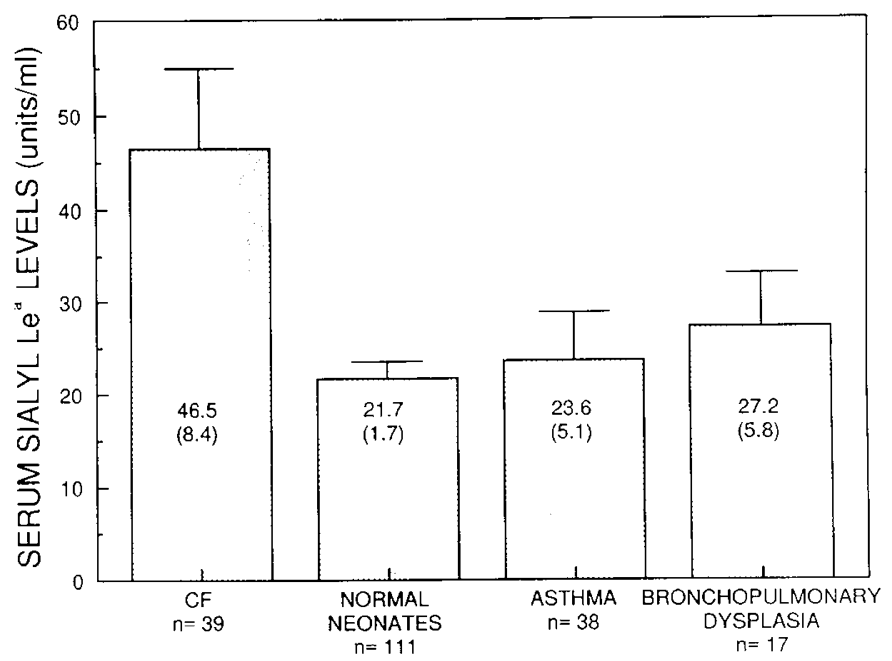

Figure 1. Mean serum sialyl Le levels by diagnosis ( $n=$ number of paticnts; SEM in parentheses). 
one-way analysis of variance revealed a significant difference among mean serum antigen levels $[F(3,205)=6.66, p<$ $0.01]$. Duncan's multiple range test revealed that the mean serum mucin level of the CF group was significantly different from the means of the other three groups $(p<0.05)$ but that the other three groups were not significantly different from one another. Furthermore, all three non-CF groups' mean serum antigen levels were well within the limits of more than 2000 normal adult blood donors' serum sialyl Le ${ }^{\mathrm{a}}$ levels, 99\% of whom had sialyl Le antigen levels less than $37 \mathrm{U} / \mathrm{mL}$ (19).

Of 111 neonates, there were 97 who expressed $\mathrm{Le}^{\mathrm{b}}$ antigen, nine who expressed only $\mathrm{Le}^{\mathrm{a}}$, and five who were $\mathrm{Le}^{\mathrm{a}-\mathrm{b}-}$. As expected, the nine normal neonates who expressed only the $\mathrm{Le}^{\mathrm{a}}$ blood group antigen in their meconium glycolipids had, on average, significantly higher serum antigen levels than their $\mathrm{Le}^{\mathrm{b}}$ counterparts $[t(104)=7.52, p<0.001]$. The range of individual serum antigen levels was great, being $<8 \mathrm{U} / \mathrm{mL}$ serum to $56 \mathrm{U} / \mathrm{mL}$ for the $\mathrm{Le}^{\mathrm{a}}$ neonates and $<8$ to $102 \mathrm{U} / \mathrm{mL}$ for $\mathrm{Le}^{\mathrm{b}}$ neonates. One of five $\mathrm{Le}^{\mathrm{a}-\mathrm{b}-}$ neonates had a barely detectable serum antigen level of $10 \mathrm{U} / \mathrm{mL}$, but the other four $\mathrm{Le}^{\mathfrak{a}-\mathfrak{b}-}$ neonates' serum sialyl Le ${ }^{\mathrm{a}}$ levels were all $<8 \mathrm{U} / \mathrm{mL}$, the lower threshold of detection. There was no statistically significant correlation between serum antigen levels and age or gender, either within groups or among all patients together.

Twenty-six CF patients were genotyped. Fourteen patients were $\Delta \mathrm{F} 508 / \Delta \mathrm{F} 508,9$ were $\Delta \mathrm{F} 508 /$, two were $\Delta \mathrm{F} 508 / \mathrm{R} 553 \mathrm{X}$, and one was $\Delta \mathrm{F} 508 / \mathrm{G} \rightarrow \mathrm{A}$. Six CF patients initially had 72-h stool collections with $<15 \%$ fecal fat concentration, although only one patient maintained pancreatic sufficiency by 1 y of age. Of the six CF patients with initial pancreatic sufficiency, two had the $\Delta \mathrm{F} 508 / \Delta \mathrm{F} 508$ genotype, one was $\Delta \mathrm{F} 508 /$ ?, and one was $\Delta \mathrm{F} 508 / \mathrm{R} 553 \mathrm{X}$; the remaining CF patient who did not have pancreatic insufficiency at $1 \mathrm{y}$ of age was of unknown genotype.

CF patients with principally respiratory manifestations of that disease had a significantly elevated mean antigen level

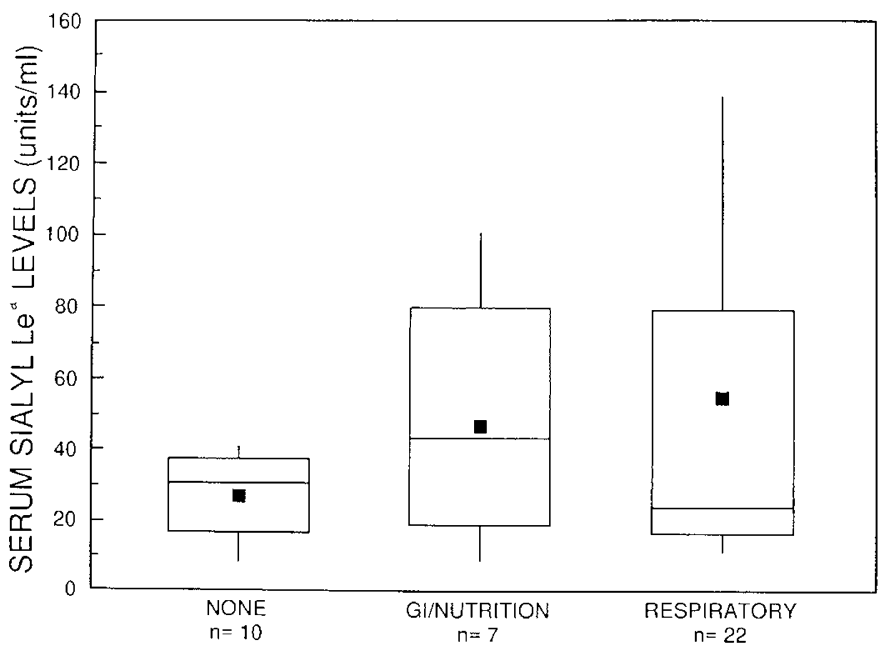

Figure 2. Serum sialyl Le levels of CF patients grouped by type of complaint or finding. In these box graphs, each group's mean serum sialyl Le ${ }^{\mathrm{a}}$ level is represented by a solid square, the horizontal lines represent the 25th, 50th (median), and 75th percentiles, and the vertical lines from the top and bottom of each rectangle extend to the 90 th and 10 th percentiles. The number of $\mathrm{CF}$ patients in each group is represented by $n$. compared with $\mathrm{CF}$ patients without findings or complaints $[t$ $(30)=14.8, p<0.001]$, but the mean antigen level of those with respiratory illness was not significantly different from that of $\mathrm{CF}$ patients with gastrointestinal or nutritive difficulties $[t$ $(30)=1.07, p>0.2)$. The CF serum mucin levels by group are shown in Figure 2.

\section{DISCUSSION}

The present data demonstrate a specific elevation of sialyl $\mathrm{Le}^{\mathrm{a}}$ antigen levels in infants and young children who have CF. We have reported previously that mucin levels are elevated in older CF patients and increase with age. Previous results suggest that the mucin antigen in serum is largely of pulmonary origin (5). How mucin secreted in the lung enters the circulation, however, is unclear. Lack of correlation between mucin levels and colonization by Pseudomonas aeruginosa (7) and detection of elevated mucin levels in the present study in infants who are less likely to have chronic infections indicates that extensive tissue damage secondary to infection is not required for antigenemia. Correlation of antigen levels in individual patients with changes in clinical status, however, suggests that the inappropriate secretion of antigen in serum depends on specific clinical manifestations of the disease rather than being a constitutive effect of the CFTR defect.

The CFTR gene is selectively expressed in serous tubules and a subpopulation of epithelial cells in collecting ducts and ciliated ducts of submucosal glands of normal individuals (20). Apical membrane expression of the CFTR protein at these sites is lost in CF patients. This loss may directly alter the composition or physical properties of mucins secreted by the affected cells or may indirectly alter the viscoelastic properties of the secreted mucin through changes in the ionic composition of the collecting ducts. Resulting obstruction of the ducts can be observed even in infants $(21,22)$ and may lead to release of the mucin into the blood.

Current information suggests a pulmonary origin of the elevated sialyl $\mathrm{Le}^{\mathrm{a}}$ antigen (mucin) levels detected in the sera of many CF patients. First, serum mucin from a single CF patient most resembled human lung mucin with respect to carbohydrate and amino acid composition (5). Second, serum sialyl $\mathrm{Le}^{\mathrm{a}}$ antigen levels correlated with measures of lung disease in two studies of groups of CF patients $(7,8)$. Third, of 39 CF patients in the present study, 22 had some evidence of lung disease when their blood was drawn. The amount of mucins from CF patients' lungs leaked into the circulation is probably quite large. This is consistent with the finding that to overwhelm the hepatic clearance of serum mucins from human cancers implanted in nude mice, massive tumor loads were required, the equivalent of a $1200-\mathrm{g}$ malignancy in a $65-\mathrm{kg}$ human (23).

Two alternative explanations for sialyl $\mathrm{Le}^{\mathrm{a}}$ elevations in $\mathrm{CF}$ patients' sera must be addressed. One is that there is a genetic linkage between the CF locus and the genes for transferases that synthesize the sialyl Le antigen. However, no association between the Lewis blood group and CF has been observed (24). The gene for the Lewis fucosyltransferase is located on chromosome $19(25,26)$, whereas the CF gene is on chromo- 
some 7 (27-29). A second explanation is that more Le ${ }^{\mathrm{a}} \mathrm{CF}$ patients were tested than were patients with $\mathrm{Le}^{\mathrm{a}}$ blood types in the other three groups. Enzyme competition for the carbohydrate substrate Gal $\beta 1-3 G 1 \mathrm{cNAc}$. . leading to the synthesis of the sialyl $\mathrm{Le}^{\mathrm{a}}$ antigen and the $\mathrm{Le}^{\mathrm{b}}$ antigen probably means people who are $\mathrm{Le}^{\mathrm{a}}$ will express more sialyl $\mathrm{Le}^{\mathrm{a}}$ on their mucins than will people whose blood type is $\mathrm{Le}^{\mathrm{b}}(11-14)$. Unfortunately, the CF patients' Lewis blood group types are unknown, but there is no obvious selection bias favoring such patients. Moreover, our own previous studies have demonstrated large elevations of sialyl $\mathrm{Le}^{\mathrm{a}}$ antigen among adult $\mathrm{CF}$ patients whose blood type is $\mathrm{Le}^{\mathrm{b}}(7)$.

Another issue is our comparison of serum mucin levels of asthma and bronchopulmonary dysplasia patients with those of CF patients. It may be argued that patients with asthma and bronchopulmonary dysplasia do not chronically produce purulent sputum as do many CF patients, and therefore their serum mucin levels cannot be compared with those of CF patients. We believe that this issue has been resolved by two studies. First, Robinson et al. (30) found the mean serum mucin level detected by their MAb 17B1 was significantly higher in a group of adult CF patients than in normal control adult patients or adult patients with chronic obstructive lung disease who produced a teaspoonful to a half cupful of sputa daily. Second, in our 1989 study, we found the mean serum mucin level as detected with the CA 19-9 MAb to be significantly higher in 81 CF patients (adults and children) with Pseudomonas in their sputa than in six bronchiectatic non-CF adults who had Pseudomonas in their sputa. With the exception of similar serum mucin elevations in both $\mathrm{CF}$ and non-CF lung transplant patients (30), elevated serum mucin levels are associated with CF lung disease rather than with either purulent or dry non-CF lung diseases.

We note that in CF pancreatic sufficiency or insufficiency is importantly influenced by genotype (31). We therefore attempted to examine the relationship of serum sialyl Le ${ }^{\mathrm{a}}$ antigen levels to pancreatic sufficiency and to genotype. However, there were only six of $39 \mathrm{CF}$ patients with pancreatic sufficiency, and pancreatic sufficiency was transient in all but one patient, so that any attempt to examine a degree of association between fecal fat concentration and serum sialyl Le $\mathrm{L}^{\mathrm{a}}$ antigen level or genotype would have been complicated by the extremely low power of any statistical test on a sample this small. We note that in the present study, although the mean antigen level of CF patients with lung disease is significantly higher than that of CF patients free of either lung or gastrointestinal and nutritional disease, it is not significantly different from the mean serum antigen level of CF patients with digestive disease (Fig. 2), but again, small sample size may preclude further detection of intra-CF group differences. Furthermore, we found in our 1989 study that elevated serum mucin levels in CF patients were related to lung disease; in that study, four CF patients with elevated serum mucin levels had insulindependent diabetes, a condition that probably precludes having enough pancreatic epithelia to secrete mucin. Therefore, we think it unlikely that there is a relationship between the $\mathrm{CF}$ patients' elevated serum sialyl Le $e^{\text {a }}$ levels and their pancreatic statuses, and suggest that, in CF, elevated serum sialyl Le $\mathrm{L}^{\mathrm{a}}$ levels are related to lung disease (phenotype) rather than to genotype.

In a previous study of $89 \mathrm{CF}$ patients (7), serum mucin levels significantly increased with age and degree of sickness. No relationship between age and serum mucin levels was noted in neonates and young children. The reasons for this apparent lack of agreement may be that CF patients in the present study were relatively well and had a limited age range ( 1 mo to $3 \mathrm{y}$ ), and thus differences in serum mucin levels at this early stage in the evolution of cystic fibrosis were too small to detect. In the 1989 study (7), the age range was from a few months to more than 40 y. Finally, because the Lewis blood group types of the CF patients in the present study are not known, it is possible that there were more $\mathrm{Le}^{\mathrm{b}}$ phenotype patients in this study than in the previous one (7), which may lead to less sialyl Le $\mathrm{Le}^{\mathrm{a}}$ antigen on mucins and therefore smaller in-group serum antigen differences for reasons explained earlier.

We previously found that sialyl $\mathrm{Le}^{\mathrm{a}}$ antigen is present on mucins in high levels in the sera of many CF patients and that preliminary evidence suggested that those levels were correlated positively with pulmonary disease and increasing age. Other investigators have confirmed our findings (8). The present study extends these observations by demonstrating that even very young CF patients have elevated sialyl Le ${ }^{a}$ levels compared with serum antigen levels of normal babies or infants and young children who have lung diseases.

Acknowledgment. The senior author thanks Centocor, Inc. of Malvern, PA, for contributing CA19-9 radioimmunoassay kits.

\section{REFERENCES}

1. Roberts DD, Monscin DL, Frates Jr RC, Chernick MS, Ginsburg V 1986 A serum test for cystic fibrosis using monoclonal antibody 19-9. Arch Biochem Biophys 245:292294

2. Duffy MJ, O'Sullivan F, McDonnell TJ, Fitzgerald MX 1985 Increased concentrations of the antigen CA $19-9$ in serum of cystic fibrosis patients. Clin Chem $31: 1245-1246$

3. Buamah PK, Cornell C, Cassells-Smith AJ, McGill A 1986 Concentration of trypsin, elastase, and carbohydrate antigen CA 19-9 in serum of cystic fibrosis patients. [letter] Clin Chem 32:913

4. Uhlenbruck G, Schcuring U, Dienst C, Kaiser D, Roth B, Skopnik H 1988 CA 19:9, CA 50, and elastasc 1 as additional markers of cystic fibrosis. Klin Padiatr 200:89-95

5. Roberts DD, Rose MC, Wang W, Chernick MS, Frates Jr RC 1990 Isolation and characterization of mucin from the serum of cystic fibrosis patients. Am J Respir Cell Mol Biol 2:373-379

6. Magnani JL, Steplewski Z, Koprowski H, Ginsburg V 1983 Identification of the gastrointestinal and pancreatic cancer-associated antigen detected by monoclonal antibody 19:9 in the sera of patients as a mucin. Cancer Res 43:5489-5492

7. Frates Jr RC, Fink RJ, Chernick MS, Brooks JO, Ginsburg V, Roberts DD 1989 Scrum mucin-associated antigen levels of cystic fibrosis patients are related to their ages and clinical statuses. Pediatr Res 25:49-54

8. Kane RE, Penny J, Walker K. Rubin BK, Wu J 1992 Changes in the CA 19-9 antigen and Lewis blood group with pulmonary disease scverity in cystic fibrosis. Pediatr Pulmonol 12:221-226

9. Del Villano BC, Brennan S, Brock P, Bucher C, Liu V, McClure M, Rake B, Space S, Westrick B, Schoemaker H, Zurawski Jr VR 1983 Radioimmunometric assay for a monoclonal antibody-defined tumor marker, CA 19-9. Clin Chem 29:549-552

10. Ginsburg V 1972 Enzymatic basis for blood groups in man. In: Mcister A (ed) Advances in Enzymology. John Wilcy \& Sons, New York, pp 131-149

11. Brockhaus M, Wysocka M, Magnani JL, Steplewski Z, Koprowski H, Ginsburg V 1985 Normal salivary mucin contains the gastrointestinal cancer-associated antigen detected by monoclonal antibody 19-9 in the serum mucin of patients. Vox Sang 48:34-38

12. Hannson GC, Zopf D 1985 Biosynthesis of the cancer-associated sialyl-Le a antigen. J Biol Chem 260:9388-9392

13. Karlsson K-A, Larson G 1981 Potential use of glycosphin-golipids of human meconium for blood group chemotyping of single individuals. FEBS Lett 1:71-74 
14. Magnani JL, Nilsson B, Brockhaus M, Zopf D, Steplewski Z, Koprowski H, Ginsburg V 1982 A monoclonal antibody-defined antigen associated with gastrointestinal cancer is a ganglioside containing sialylated lacto- $N$-fucopentaose II. $\mathrm{J}$ Biol Chem 257:14365-14369

15. Hammond KB, Abman SH, Sokol RJ, Accurso SJ 1991 Efficacy of statewide neonatal screening for cystic fibrosis by assay of trypsinogen concentrations. N Engl J Med 325:769-774

16. Gibson LE, Cooke RE 1959 A test for concentration of electrolytes in sweat in cystic fibrosis of the pancreas utilizing pilocarpine by iontophoresis. Pediatrics 23:545-549

17. Tsui L-C 1992 Mutations and sequence variations detected in the cystic fibrosi transmembrane conductance regulator (CFTR) gene: a report from the Cystic Fibrosis Genetic Analysis Consortium. Hum Mutat 1:197-208

18. Northway WH, Rosan RC, Parker DY 1967 Pulmonary disease following respiratory therapy of hyaline membrane disease. N Engl J Med 276:357-374

19. Ritts Jr RE, Del Villano BC, Go VLW, Herberman RB, Klug TL, Zurawski VR 1984 Initial clinical evaluation of an immuno-radioimmunometric assay for CA 19-9 using the NCI serum bank. Int J Cancer 33:339-345

20. Engelhardt JF, Yankansas JR, Ernst SA, Yang Y, Marino CR, Boucher RC, Cohn JA Wilson JM 1992 Submucosal glands are the predominant sitc of CFTR expression in the human bronchus. Nat Genet 2:240-248

21. Oppenheimer EH, Estcrly JR 1975 Pathology of cystic fibrosis: review of the literature and comparison with 146 autopsied cases. In: Rosenberg HS, Bolano RP (eds) Perspectives in Pediatric Pathology. Year Book, New York, pp 241-278

22. Tizzano EF, O'Brodovich H, Chitayat D, Benichou J-C, Buchwald M 1994 Regiona expression of CFTR in developing human respiratory tissues. Am J Respir Cell Mol Biol 10:355-362
23. Cerani RL, Blank EW 1991 Breast epithelial mucin serum clearancc. Cancer Lett $58: 65-68$

24. Steinberg AG, Shwachman H, Allen Jr FH, Dooley RR 1956 Linkage studies with cystic fibrosis of the pancreas. Am J Hum Genet 6:162-176

25. Kukowska-Latallo J, Larsen RD, Nair RP, Lowc JB 1990 A cloned human CDNA determines expression of a mouse staged-specific embryonic antigen and the Lewis blood group $\alpha(1,3 / 1,4)$ fucosyltransferase. Gencs Dev 4:1288-1303

26. Weston BW, Nair RP, Larsen RD, Lowe JB 1992 Isolation of a novel human $\alpha(1,3)$ fucosyltransferase gene and molecular comparison to the human Lewis blood group $\alpha(1,3 / 1,4)$ fucosyltransferase gene. J Biol Chem 267:4152-4160

27. White R, Woodward S, Leppert M, O'Connell P, Hoff M, Herbst J, Lalouel J-M, Dean $\mathrm{M}$, Vande Woude G 1985 A closely linked genetic marker for cystic fibrosis. Nature 318:382-384

28. Knowlton RG, Cohen-Haguenaur O, Nguyen VC, Frézal J, Brown VA, Barker D, Braman JC, Schumm JW, Tsui L-C, Buchwald M, Donis-Keller H 1985 A polymorphic DNA marker linked to cystic fibrosis is located on chromosome 7. Nature 267:380-382

29. Waingwright BJ, Scambler PJ, Schmidtke J, Watson EA, Low H-Y, Farrall M, Cooke HJ, Eiberg H, Williamson R 1985 Localization of cystic fibrosis locus to human chromosome 7 cen-q22. Nature 267:384-385

30. Robinson CB, Martin WR, Ratliff JL, Holland PV, Wu R, Cross CE 1993 Elevated levels of serum mucin-associated antigen in adult patients with cystic fibrosis. Am Rev Respir Dis 148:385-389

31. The Cystic Fibrosis Genotype-Phenotype Consortium 1993 Correlation between genotype and phenotype in patients with cystic fibrosis. N Engl J Med 329:1308-1313 